\title{
Which Biomarker is most Effective to Determine Severity of Acute Head Trauma in the Experimental Animal Head Trauma Model?
}

\author{
Ozgur DEMIR ${ }^{1}$, Fatih Ersay DENIZ1 , Ismail BENLI², Erol OKSUZ1', Osman DEMIR ${ }^{3}$, Ilknur BUTUN² \\ ${ }^{1}$ Gaziosmanpaşa University, School of Medicine, Department of Neurosurgery, Tokat, Turkey \\ ${ }^{2}$ Gaziosmanpaşa University, School of Medicine, Department of Biochemistry, Tokat, Turkey \\ ${ }^{3}$ Gaziosmanpaşa University, School of Medicine, Department of Biostatistics, Tokat, Turkey
}

\section{ABSTRACT}

AIM: Because of the need for effective method to determine the severity of head trauma, the importance of biomarkers is recognized recently. This study aims to analyze the values of sera levels of some biomarkers and the relation with their tissue levels in acute head injury.

MATERIAL and METHODS: In this study, rats were divided into three groups (mild head trauma, severe head trauma and control group). All rats were anaesthetized. Weightdrop method was used as trauma method. Blood samples were obtained five minutes after trauma when the acute effects of trauma occurred. Then whole brains of rats were excised. Levels of biomarkers were investigated in the sera samples and homogenized brain tissues biochemically.

RESULTS: Significant differences in the sera GFAP $(p=0.015)$ and insulin $(p=0.011)$ levels were observed. Very significant difference in the sera nNOS level was observed. Extremely significant difference in the tissue IL- $6(p<0.001)$ level was observed between all groups.

CONCLUSION: Sera nNOS and tissue IL-6 are the best biomarkers to predict trauma severity. Sera GFAP and insulin are also capable to show trauma severity in the very acute period of postinjury. Tissue levels of the biomarkers except insulin are higher than their sera levels.

KEYWORDS: Craniocerebral Trauma, Brain injury, Biomarker

\section{INTRODUCTION}

Traumatic brain injury (TBI) is a major cause of death and disability worldwide. Some of the patients who survive severe head injury due to intensive therapy in the acute stage make a satisfactory recovery. Several typical questions confront the neurosurgeon regarding the extent of injury and prognosis. Because there is such marked heterogeneity in TBI, predicting the outcome is difficult, as is deciding on optimal treatment (13).
Traditionally, TBI has been acutely diagnosed and classified by neurological examinations and neuroimaging. Clinical examination has limited ability to assess injury severity or predict outcome. Patients with mild head injury usually have few clinical symptoms but may be at risk of later deterioration. Even in the absence of neurological deterioration, many patients suffer long-term sequelae $(13,14)$.

Imaging of the brain fares little better. Computerized tomography (CT) scanning of the brain has a low sensitivity for detecting diffuse brain damage, and repeated scans for 
recurrent injuries for the re-evaluation of existing injuries cause high-dose radiation intake. Although magnetic resonance imaging (MRI) is more sensitive, it is usually difficult to scan ventilated, often hemodynamically unstable patients $(13,14)$.

All of these reasons have led to a search for alternative methods of assessing injury. Due to these issues, biomarkers have been recognized and introduced recently. A variety of neurochemical substances have been proposed as markers of cerebral cell damage for this purpose. An ideal TBI biomarker should be brain-tissue specific, able to cross the blood-brain barrier into the bloodstream within minutes of injury, and able to be detected using a point-of-care blood test, although some biomarkers will only be detectable in cerebral tissue $(12,13,27)$. In the present study, glial fibrillary acidic protein (GFAP), neuronal nitric oxide synthase (nNOS), interleukin-6 (IL-6), insulin and ethanol were studied and compared with each other in sera and cerebral tissue as markers to show usefulness in the very acute period of postinjury. There is no comparative study in the literature which shows the levels of biomarkers as early as 5 minutes postinjury.

\section{MATERIAL and METHODS}

This study was approved by the Gaziosmanpaşa University Experimental Research Unit and Ethics Committee for Laboratory Animals. Thirty-six adult male Wistar-Albino rats weighing $300-450 \mathrm{~g}$ were used in this study. The study took place at a laboratory of Gaziosmanpaşa University, Faculty of Medicine, Laboratory Animal Research Center. The animals were divided into three groups: (1) mild head trauma group $(n=12)$; (2) severe head trauma group $(n=12)$; (3) control group $(n=12)$. Rats in the study were randomly divided into three groups. Before the intervention, all the rats received $30 \mathrm{mg} /$ $\mathrm{kg}$ Chloral hydrate by the intraperitoneal route. Head trauma was induced using Marmarou's weight-drop method (12) modified by Uçar et al (23). The trauma device consists of a column of weights falling freely by gravity from a designated height through a tube. Injury severity can be controlled directly related to the mass and the height from which the weight is released. In Group I (mild head trauma), head injury was induced using 350 g-1 m weight-height impact; in Group II (severe head trauma), head injury was induced using $450 \mathrm{~g}-1$ $\mathrm{m}$ weight-height impact. Studies showed that Marmarou's brain trauma model induced perivascular brain edema, already visible at the ultrastructural level 5 minutes after the injury (24). Blood samples of traumatized rats were taken by intracardiac intervention 5 minutes after trauma. All rats were killed after blood samples were taken and their brain tissues extracted for biochemical studies. There were normal brain tissues in the control group (Figure 1). There were some contusions and hematomas in the brains of the mild head injury group (Figure 2). There were depressed skull fractures with intra and extra cerebral hematomas in the brains of the severe head injury group (Figure 3). The cerebral tissues were homogenized in five volumes of ice-cold tris- $\mathrm{HCl}$ buffer (50 $\mathrm{mM}, \mathrm{pH}=7.4)$ containing $0.50 \mathrm{~mL} / \mathrm{l}$ Triton $\mathrm{x}-100$. Then, the homogenization procedure (homogenizer: IKA Ultra-Turrax $T$ 25 Basic, Germany) was carried out for $2 \mathrm{~min}$ at 13,000 rpm.
All procedures were performed at $4^{\circ} \mathrm{C}$. IL-6, GFAP, ethanol, insulin, nNOS levels were then studied in the collected sera and tissue samples with the same methods (Table I).

Results were evaluated by statistical analysis. Continuous variables were expressed as mean \pm standard deviation (SD). The Shapiro-Wilks test was used to evaluate whether the distributions of continuous variables were normal. According to whether the continuous variables had a normal distribution or not, the paired sample t test was used to compare differences between paired measurements. According to whether the continuous variables had a normal distribution or not, one-way

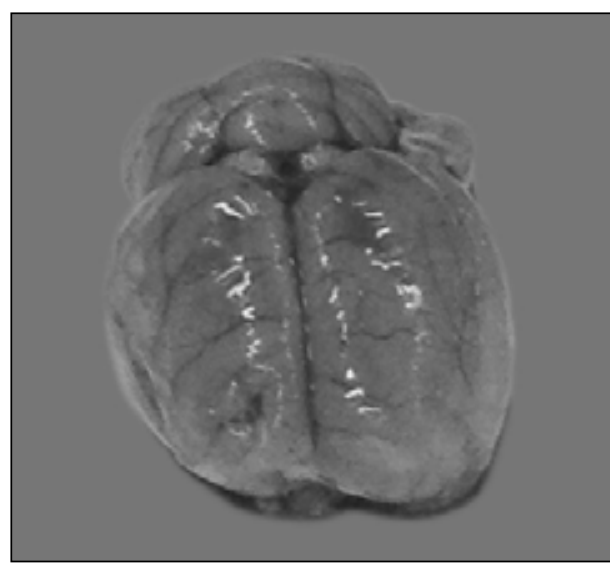

Figure 1:

Photo showing extracted brain tissue of a rat in control group.

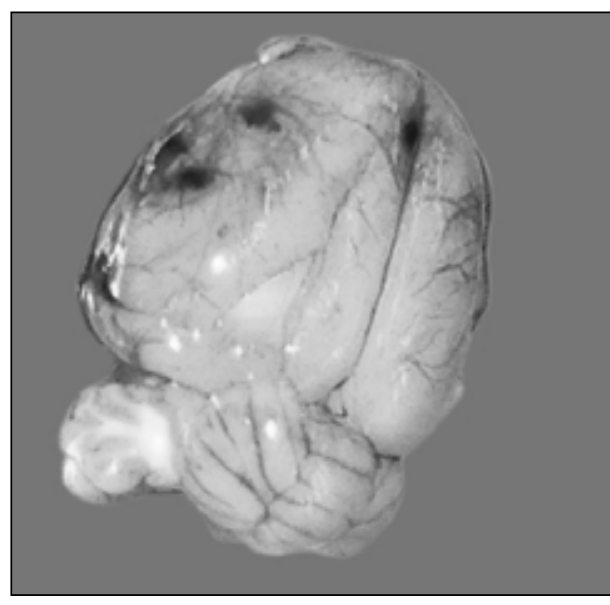

Figure 2:

Photo showing extracted brain tissue of a rat in mild head injury group after trauma.

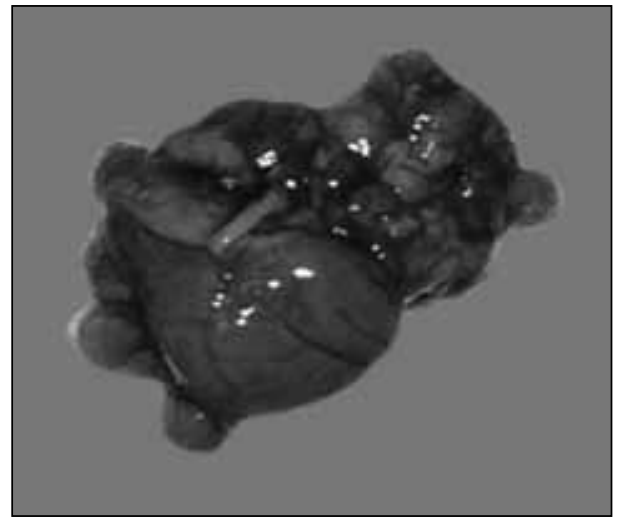

Figure 3:

Photo showing extracted brain tissue of a rat in severe head injury group after trauma. 
Demir O. et al: Head Trauma and Biomarkers

Table I: Biochemical Substances, Methods and Devices

\begin{tabular}{|c|c|c|c|c|c|c|}
\hline & Firm & Name & $\begin{array}{l}\text { Catalog } \\
\text { Number }\end{array}$ & Country & Method & Device \\
\hline Insulin & SPI-BIO & $\begin{array}{l}\text { Rat insulin enzyme } \\
\text { immunoassay kit }\end{array}$ & A05105 & $\begin{array}{l}\text { Montigny Le } \\
\text { Bretonneux, } \\
\text { France }\end{array}$ & $\begin{array}{c}\text { Enzyme } \\
\text { Immunoassay (EIA) }\end{array}$ & Manual \\
\hline IL-6 & $\begin{array}{c}\text { Demeditec } \\
\text { Diagnostics } \mathrm{GmbH}\end{array}$ & $\begin{array}{c}\text { Interleukin-6 rat } \\
\text { ELISA }\end{array}$ & DE4845 & $\begin{array}{l}\text { Kiel, } \\
\text { Germany }\end{array}$ & $\begin{array}{l}\text { Enzyme Linked } \\
\text { Immunosorbent } \\
\text { Assay (ELISA) }\end{array}$ & Manual \\
\hline nNOS & $\begin{array}{l}\text { Hangzhou } \\
\text { Eastbiopharm Co., } \\
\text { Ltd. }\end{array}$ & $\begin{array}{c}\text { Rat neuronal nitric } \\
\text { oxide synthase } \\
\text { (nNOS) ELISA Kit }\end{array}$ & CK-E30337 & Hangzhou, China & $\begin{array}{l}\text { Enzyme Linked } \\
\text { Immunosorbent } \\
\text { Assay (ELISA) }\end{array}$ & Manual \\
\hline GFAP & $\begin{array}{c}\text { Hangzhou } \\
\text { Eastbiopharm Co., } \\
\text { Ltd. }\end{array}$ & $\begin{array}{c}\text { Rat glial fibrillary } \\
\text { acidic protein (GFAP) } \\
\text { ELISA Kit }\end{array}$ & CK-E90138 & Hangzhou, China & $\begin{array}{l}\text { Enzyme Linked } \\
\text { Immunosorbent } \\
\text { Assay (ELISA) }\end{array}$ & Manual \\
\hline
\end{tabular}

Table II: The Scheme that Prism Uses

\begin{tabular}{lcc}
\hline $\mathbf{P}$ value & Wording & Summary \\
\hline$<0.0001$ & Extremely significant & $* \star \star \star$ \\
\hline $0.001-0.0001$ & Extremely significant & $* \star *$ \\
\hline $0.01-0.001$ & Very significant & $*$ \\
\hline $0.05-0.01$ & Significant & $*$ \\
\hline$>0.05$ & Not significant & ns \\
\hline
\end{tabular}

analysis of variance (ANOVA) and Kruskal-Wallis analysis of variance were used to compare continuous variables between groups. In the one-way analysis of variance (ANOVA), for post hoc multiple comparison, the Least Significant Difference test was used. $p$ values below 0.05 were considered statistically significant. Statistical analysis was performed by using commercial software (IBM SPSS Statistics 19, SPSS inc., an IBM Co., Somers, NY). Additonally, Box and Whisker plot were used for standardized variables in all groups. We used the Prism scheme to evaluate the $p$ values (Table II).

\section{RESULTS}

We compared tissue and sera values of insulin in a group with the values of insulin in the other groups. We found significant differences $\left({ }^{*}\right)$ between all groups $(p=0.011)$ when we examined sera levels of insulin. Insulin was higher in the severe head injury group than the control group $(p=0.013)$ and mild head injury group $(p=0.005)$. No significant differences (ns) were found between the groups when we examined tissue insulin levels (Table III, IIIA-D). We trauma-independently compared tissue average values of insulin with their sera average values. We found extremely significant differences $\left.{ }^{(* \star}\right)$ between average tissue and sera levels $(p<0.001)$. Sera average value of insulin was higher than tissue insulin value. We trauma-dependently compared tissue average values of insulin with their sera average values. In severe head injury group we found extremely significant differences $\left(^{\star \star *}\right)$ between average tissue and sera levels $(p<0.001)$. In mild head injury and control group there was very significant difference $\left(^{* \star}\right)$ between average tissue and sera level $(p=0.004, p=0.004)$. Sera average value of insulin was higher than tissue insulin value (Table IV-VII).

We compared tissue and sera values of IL-6 in a group with the values of IL- 6 in the other groups. We found extremely significant differences $\left(^{* * *}\right)$ between all groups $(p<0.001)$ when we examined tissue levels of IL-6. Decrease occurred in severe head injury group when we compared with control $(p<0.001)$ and mild head injury group $(p<0.001)$. Also decrease occurred in mild head injury group when we compared with control group $(p<0.001)$. No significant differences $(n s)$ were found between all groups when we examined sera IL-6 levels (Table III, IIIA-D). We trauma-independently and -dependently compared tissue average values of IL- 6 with their sera average values. We found extremely significant differences $\left({ }^{* \star *}\right)$ between average tissue and sera levels $(p<0.001)$. Tissue average values of IL- 6 were higher than their sera values (Table IV-VII).

We compared tissue and sera values of nNOS in a group with the values of nNOS in the other groups. Sera nNOS levels were studied and very significant difference $\left(^{* *}\right)$ was observed between all groups. nNOS was lower in severe head injury group than control $(p=0.010)$ and mild head injury group $(p=0.004)$. No significant differences (ns) were found between all groups when we examined tissue nNOS levels (Table III, IIIA-D). We trauma-independently and -dependently compared tissue average values of nNOS with their sera 
Table III: Distribution of Quantitative Variables According to the Variable Sample Name

\begin{tabular}{|c|c|c|c|c|}
\hline & Severe Head Injury Group & Control Group & Mild Head Injury Group & p Value \\
\hline Variables & Standard Deviation & Standard Deviation & Standard Deviation & \\
\hline Ethanol Sera & $0.84 \pm 0.82$ & $0.49 \pm 0.58$ & $0.67 \pm 0.62$ & 0.481 (ns) \\
\hline Ethanol Tissue & $0.97 \pm 0.08$ & $1.03 \pm 0.05$ & $0.99 \pm 0.07$ & 0.085 (ns) \\
\hline Insulin Sera & $1.21 \pm 0.29$ & $0.8 \pm 0.43$ & $0.74 \pm 0.38$ & $0.011\left(^{\star}\right)$ \\
\hline Insulin Tissue & $0.33 \pm 0.19$ & $0.31 \pm 0.21$ & $0.29 \pm 0.23$ & 0.859 (ns) \\
\hline IL-6 Sera & $268.23 \pm 24.85$ & $254.53 \pm 26.86$ & $262.15 \pm 17.56$ & 0.541 (ns) \\
\hline IL-6 Tissue & $2732.68 \pm 600.34$ & $4756.02 \pm 568.65$ & $3672.9 \pm 586.5$ & $<0.001\left(^{* * *}\right)$ \\
\hline nNOS Sera & $3.5 \pm 0.5$ & $3.94 \pm 0.28$ & $4.01 \pm 0.35$ & $0.008\left(^{* \star}\right)$ \\
\hline nNOS Tissue & $20.22 \pm 3.04$ & $18.27 \pm 1.77$ & $19.57 \pm 1.85$ & 0.121 (ns) \\
\hline GFAP Sera & $344 \pm 71.79$ & $385.43 \pm 107.94$ & $463.53 \pm 90.49$ & $0.015\left(^{*}\right)$ \\
\hline GFAP Tissue & $1293.24 \pm 302.97$ & $1112.37 \pm 206.96$ & $1355.43 \pm 245.54$ & 0.067 (ns) \\
\hline
\end{tabular}

Table IIIA: Box and Whisker Plot for Standardized Variables at all Groups

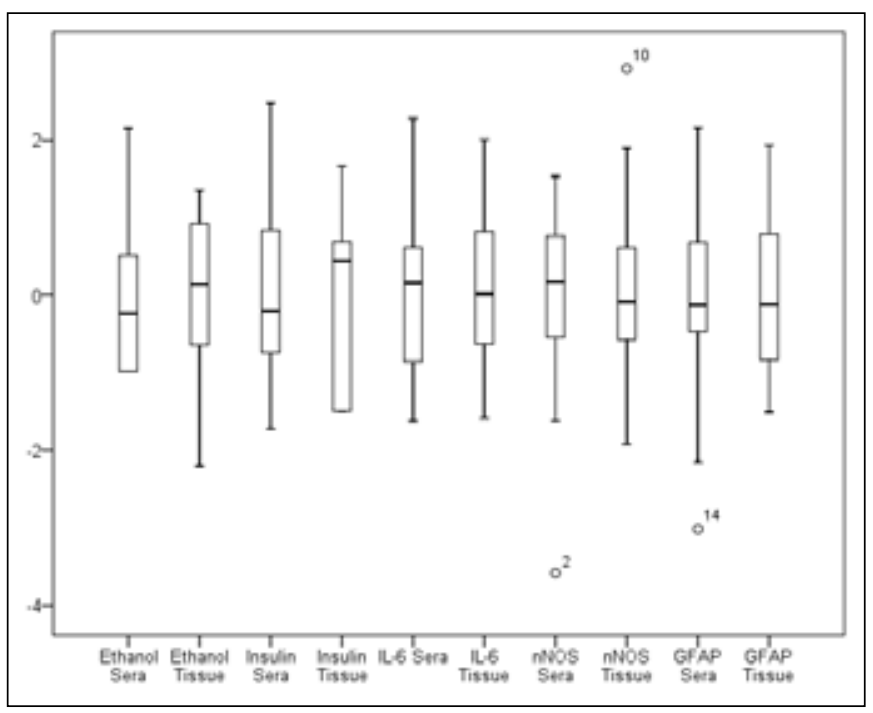

Table IIIC: Box and Whisker Plot for Standardized Variables at Severe Head Injury Group

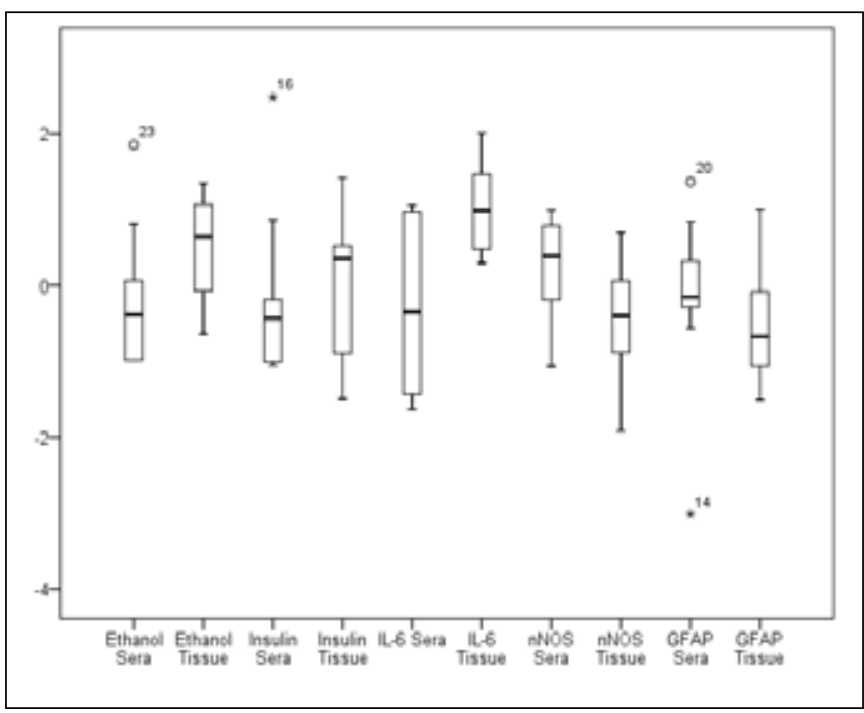

Table IIIB: Box and Whisker Plot for Standardized Variables at Control Group

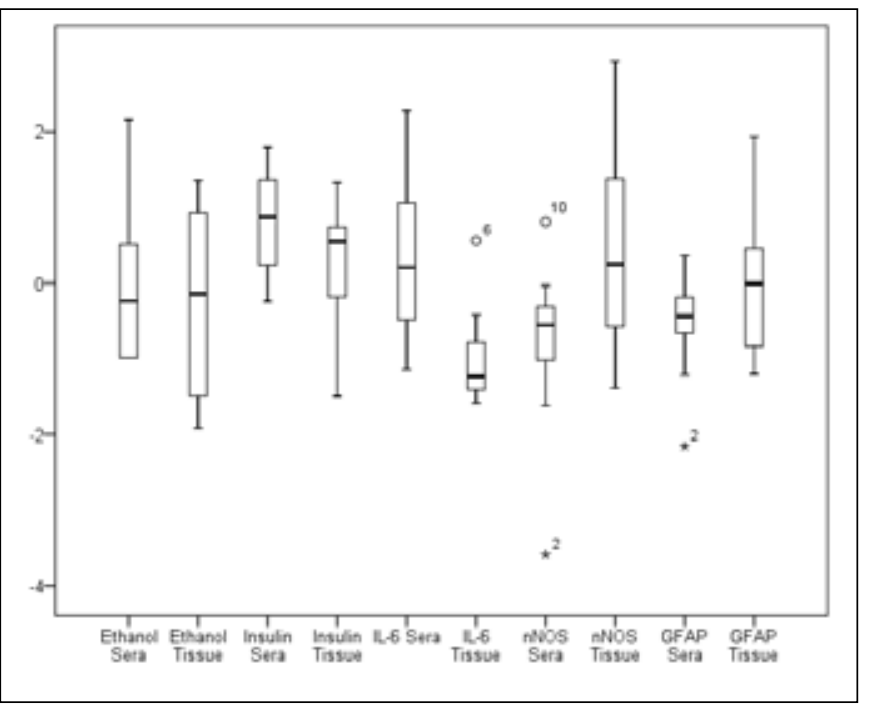

Table IIID: Box and Whisker Plot for Standardized Variables at Mild Head Injury Group

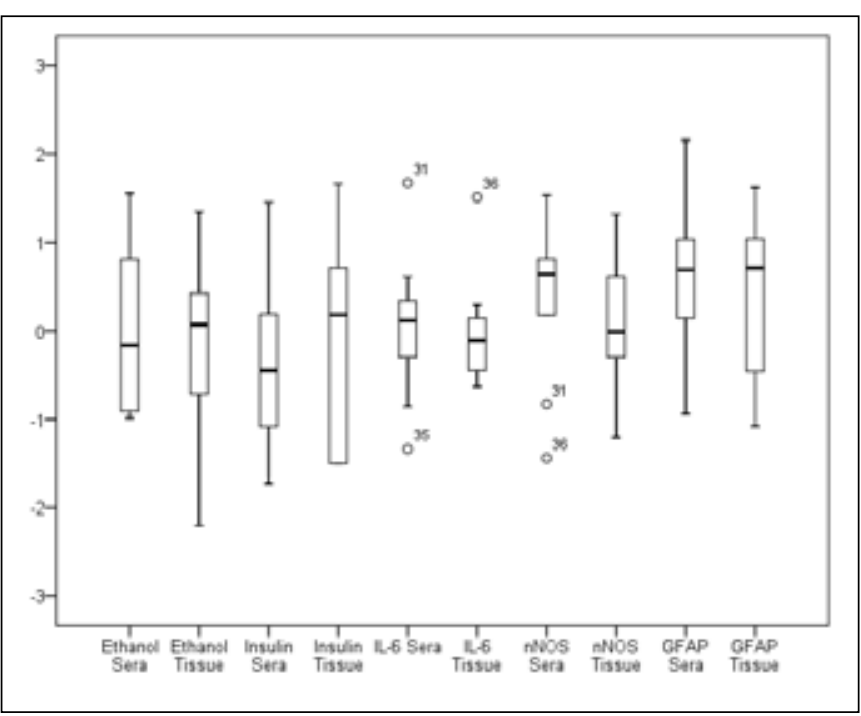


average values. We found extremely significant differences $\left({ }^{* \star *}\right)$ between average tissue and sera levels $(p<0.001)$. Tissue average values of $\mathrm{nNOS}$ were higher than their sera values (Table IV-VII).

We compared tissue and sera values of GFAP in a group with the values of GFAP in the other groups. When we examined sera GFAP levels, significant difference $\left(^{*}\right)$ was observed between all groups $(p=0.015)$. GFAP was lower in severe head injury group than mild head injury group $(p=0.005)$. GFAP was higher in mild head trauma group than control group $(p=0.047)$. No significant differences (ns) were found between all groups when we examined tissue GFAP levels (Table III, IIIA-D). We trauma-independently and -dependently compared tissue average values of GFAP with their sera average values. We found extremely significant differences $\left({ }^{\star \star \star}\right)$ between average tissue and sera levels $(p<0.001)$. Tissue average values of GFAP were higher than their sera values (Table IV-VII).

We compared tissue and sera values of ethanol in a group with the values of ethanol in the other groups. No significant differences (ns) were found between all groups when we examined tissue and sera ethanol levels (Table III, IIIA-D). We trauma-independently compared tissue average values of ethanol with their sera average values. We found very significant differences $\left({ }^{\star \star}\right)$ between average tissue and sera levels $(p=0.006)$. Tissue average values of ethanol were higher than their sera values. We trauma-dependently compared tissue average values of ethanol with their sera average values. We found not significant difference (ns) between average tissue and sera levels in severe and mild head injury group $(p=0.575, p=0.112)$. There were very significant differences $\left({ }^{* \star}\right)$ between average tissue and sera levels of ethanol $(p=0.008)$ in control group. Tissue average values of ethanol were higher than their sera values (Table IV-VII).

\section{DISCUSSION}

Actual methods have limited ability to assess injury severity. Recently biomarkers are recognized to assess injury severity. There are some reports in the literature to determine the

Table IV: Comparison with Quantitative Variables in Trauma Independent Study (t Test for Paired Samples)

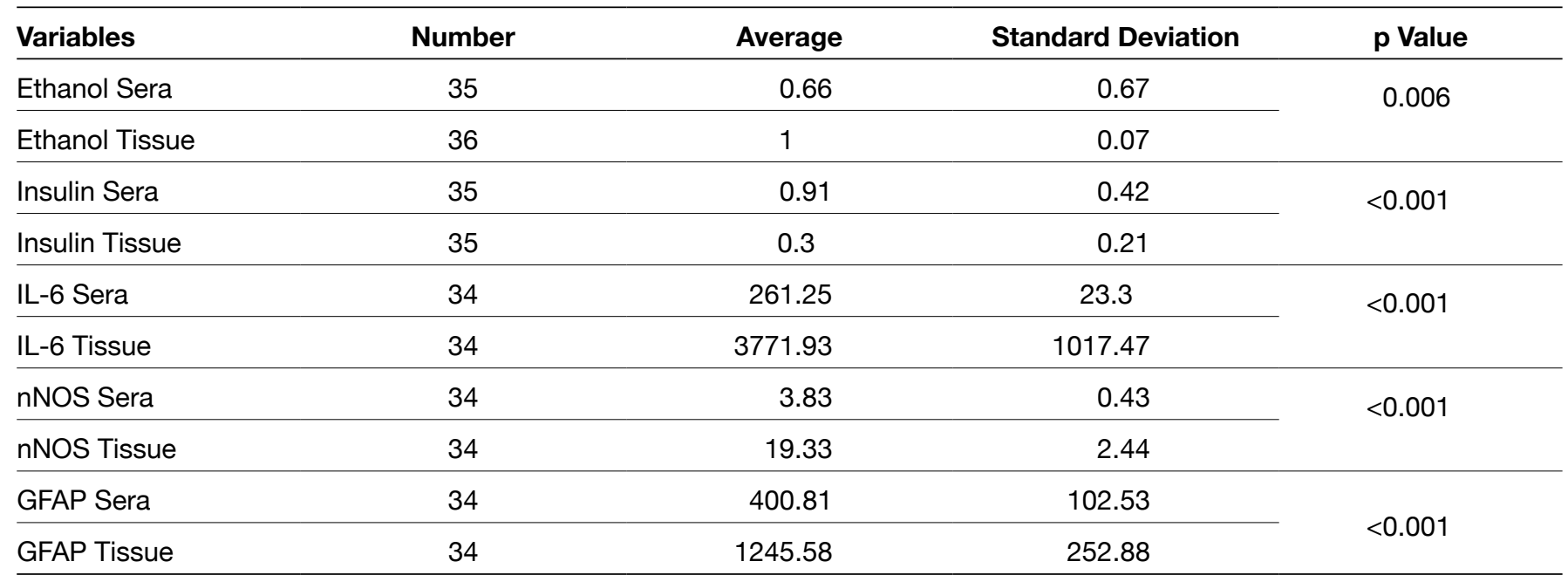

Table V: Comparison with Quantitative Variables in Severe Head Injury Group (t Test for Paired Samples)

\begin{tabular}{lcccc}
\hline Variables & Number & Average & Standard Deviation & p Value \\
\hline Ethanol Sera & 11 & 0.8364 & 0.81642 & \multirow{2}{*}{0.575} \\
\cline { 1 - 4 } Ethanol Tissue & 11 & 0.9764 & 0.08213 & \multirow{2}{*}{0.001} \\
\hline Insulin Sera & 11 & 1.21 & 0.29 & \\
\hline Insulin Tissue & 11 & 0.33 & 0.2 & \multirow{2}{*}{$<0.001$} \\
\hline IL-6 Sera & 10 & 268.23 & 24.85 & $<0.001$ \\
\hline IL-6 Tissue & 10 & 2709.85 & 0.050 .03 & \\
\hline nNOS Sera & 10 & 3.5 & 3.35 & $<0.001$
\end{tabular}


Table VI: Comparison with Quantitative Variables in Control Group (t Test for Paired Samples)

\begin{tabular}{lcccc}
\hline Variables & Number & Average & Standard Deviation & p Value \\
\hline Ethanol Sera & 12 & 0.4917 & 0.58225 & 0.008 \\
\hline Ethanol Tissue & 12 & 1.03 & 0.04767 & 0.43 \\
\hline Insulin Sera & 12 & 0.8 & 0.21 & 0.004 \\
\hline Insulin Tissue & 12 & 0.31 & 26.86 & $<0.001$ \\
\hline IL-6 Sera & 12 & 254.53 & 568.65 & 0.43 \\
\hline IL-6 Tissue & 12 & 4756.02 & 2.44 & $<0.001$ \\
\hline nNOS Sera & 12 & 3.94 & 107.94 & 206.96 \\
\hline nNOS Tissue & 12 & 18.27 & & $<0.001$
\end{tabular}

Table VII: Comparison with Quantitative Variables in Mild Head Injury Group (t Test for Paired Samples)

\begin{tabular}{lcccc}
\hline Variables & Number & Average & Standard Deviation & p Value \\
\hline Ethanol Sera & 12 & 0.6667 & 0.61693 & 0.112 \\
\hline Ethanol Tissue & 12 & 0.9867 & 0.06638 & 0.38 \\
\hline Insulin Sera & 12 & 0.74 & 0.23 & 0.004 \\
\hline Insulin Tissue & 12 & 0.29 & 17.56 & $<0.001$ \\
\hline IL-6 Sera & 12 & 262.15 & 586.5 & 0.35 \\
\hline IL-6 Tissue & 12 & 3672.9 & 1.85 & $<0.001$ \\
\hline nNOS Sera & 12 & 4.01 & 90.49 & 245.54 \\
\hline nNOS Tissue & 12 & 19.57 & 0.001
\end{tabular}

ability and accuracy of biomarkers in predicting severity after a moderate or severe traumatic brain injury $(13,14$, 27). This study aims to analyze the values of blood GFAP, insulin, nNOS, ethanol and IL-6 levels and the relation with their tissue levels in acute TBI. Tissue and blood levels were studied simultaneously and compared with each other by using statistical analysis and the Prism scheme. There is no comparative study in the literature like this presented study.

GFAP is expressed in the central nervous system (CNS) in astrocyte cells. It is involved in many important CNS processes, including cell communication and the functioning of the blood brain barrier. GFAP is released in the blood stream soon after TBI. GFAP is not released in multiple trauma without TBI. It is related to the TBI level of severity with the Marshall Classification and presence of intracranial hemorrhages $(\mathrm{ICH})$. GFAP was found to be higher in patients with a primary fatal outcome and with a worse neurological outcome $(15,16,20)$.

In the present study, we compared tissue and sera values of GFAP in the different groups in the very early period of post-injury. Serum GFAP levels were found to be significantly increased $\left(^{*}\right)$ in mild injury group when compared with the control group. This result is consistent with the literature. However, GFAP levels in the severe head injury group were found to be very significantly decreased $\left(^{\star *}\right)$ when compared with the mild head injury group. This result requires further studies to show the time-course and severity-dependent changes of the serum GFAP level.

GFAP expression occurs in the cerebral tissue at all degrees of head injury. The presence of GFAP indicates the activation of glial cells, astrocytes and microglia in these areas, and thus, glial scarring occurred in even the mildest TBI. However, peak activation was observed 5 to 7 days after head injury (6). We examined tissue GFAP levels and found no significant difference (ns) between all groups. So this result may due to time-dependent expression of GFAP in cerebral tissue after TBI.

Nitric oxide (NO) is the major regulator of cerebral blood flow. In addition, it inhibits platelet adherence and aggregation, 
reduces adherence of leukocytes to the endothelium, and suppresses vessel injury. NO, as a free radical, has been effective in reducing neuronal damage in animal models of brain injury. NO produced by nNOS contributes to neuron damage after traumatic, ischemic or excitotoxic insult. The serum nNOS level was found to be related with head trauma severity $(3,4,28)$.

Some reports showed time-dependent alterations of nNOS level after TBI. The serum nNOS level decreases, recovers and increases (25). In the present study, the serum nNOS level in the severe head injury group decreased very significantly $\left({ }^{* *}\right)$ when compared with the control group and mild head injury group 5 minutes after trauma. Reduction of serum nNOS level in the acute period of posttrauma may be due to the increase in use.

Detection of nNOS level in cerebral tissue is very difficult because of its very short half-life time. Some special methods were used to detect tissue nNOS level (21). When we examined tissue nNOS level we found no significant difference between the groups. This result may be due to the method that we used.

IL-6 is the cytokine found in the largest quantity in the circulation in response to inflammatory or traumatic insults, acting in both systemic and local responses. IL-6 acts as a cellular mediator for immunological responses and can be produced through inflammatory events in the central nervous system. In cases of cerebral damage, IL-6 plasmatic levels were increased. Some reports showed that serum IL-6 levels were related with trauma severity. The serum IL-6 was found to reach its peak level within days after the injury $(7,9,26)$. In our study, we found no significant differences (ns) between all groups 5 minutes after trauma when we studied serum IL-6 levels. This result may be due to time-dependent changes of serum IL-6 levels after TBI.

Some authors reported that cerebral tissue IL-6 levels can show head trauma severity and increase within hours (22). In our study we detected that the tissue IL-6 level decreased in severe head injury group when compared with the control and mild head injury group. Also when we compared the mild head injury group with the control group, a decrease was detected. The differences were found to be extremely significant ${ }^{* \star *}$ ). There are some reports including the posttraumatic time course of the cerebral tissue IL-6 level. However, there is no study in the literature that shows the tissue IL-6 level as early as 5 minutes postinjury. This result may be due to the increase in use in the very early posttraumatic period.

Brain injury is associated with a sympathetic-adrenomedullary response that leads to increased levels of circulating norepinephrine, epinephrine, and dopamine with resultant hyperglycemia and insulinemia. Some reports described an association between insulinemia and increased mortality in head-injured patients. Both blood glucose and insulin concentration were found to be increased markedly in TBI $(2$, $17,18)$. In the present study we examined serum insulin levels and we found significant increase $\left(^{*}\right)$ in severe head injury group when we compared with control and mild injury group.
This result is consistent with the literature even in the very early period of postinjury.

The brain is not generally considered to be an insulin-dependent tissue. There is no report in the literature that shows homogenized cerebral tissue insulin levels after head trauma. However, there are studies in the literature that confirmed the presence of a specific insulin receptor on brain microvessels. Although insulin does not cross the blood-brain barrier, the presence of an insulin receptor provides a possible mechanism by which blood-borne insulin can influence brain cell metabolism $(8,19)$. We therefore studied the tissue insulin level and found no significant difference (ns) between the groups. Further investigations must be done in order to understand the relationship between insulin and cerebral tissue after TBI.

The fermentation of sugar into ethanol is one of the earliest biotechnologies employed by humans. The intoxicating effects of ethanol consumption have been known since ancient times. Ethanol has been used by humans since prehistory as the intoxicating ingredient of alcoholic beverages. With depressant effects on the CNS, it has a complex mode of action and affects multiple systems in the brain, most notably increasing the activity of GABA receptors. Recently some reports showed a neuroprotective effect of externally supplied ethanol $(1,10)$. Over the years, many determinations of endogenous ethanol have been made. Carbohydrate-rich foods and very serious yeast infections were found to be responsible $(5,11)$. We tried to find an answer to the following question: 'Do our bodies produce endogenous ethanol in order to protect the CNS after head trauma?' For the very early posttraumatic period, the answer is no. We studied serum and tissue ethanol levels and found no significant difference (ns) between the groups. We believe that time-course levels of ethanol must be measured to understand the relation between ethanol and TBI.

There is no comparative study in the literature which examined tissue and sera levels of the biomarkers simultaneously. In the present study we found that; tissue average values of nNOS, IL-6 and GFAP were higher than their sera levels in the traumaindependent and -dependent groups. When we examined nNOS, IL-6 and GFAP, extremely significant differences $\left({ }^{\star \star \star}\right)$ were found between their sera and tissue values in all groups. So differences didn't change with trauma. GFAP and nNOS are neuron specific biomarkers. Although IL- 6 is not neuron specific biomarker, cerebral tissue level was higher than sera level. This situation explains why IL-6 is good biomarker for head trauma.

When we examined insulin; sera average value was higher than their tissue level in all groups. Between insulin average values of sera and tissue there were very significant differences $\left.{ }^{(*}\right)$ in control and mild head injury group and there was extremely significant difference $\left(^{* \star *}\right)$ in severe head injury group. This result may be due to more increase of insulin in sera than in tissue with trauma severity.

When we examined ethanol; tissue ethanol levels were higher than sera levels in control group and trauma-independent analysis. There were very significant differences $\left({ }^{\star *}\right)$ between average tissue values and average sera values in these 
groups. But there were not significant differences (ns) were found between them in trauma groups. This result may be due to more increase of ethanol in sera than in tissue with trauma.

\section{CONCLUSION}

This study aimed to show the usefulness of widely used biomarkers as early as 5 minutes after trauma when effects of trauma are already visible at the ultrastructural level. In this way we could tell which biomarker is more sensitive. Sera nNOS and tissue IL-6 are the best biomarkers to predict trauma severity. Sera GFAP and insulin are also valuable biomarkers in TBI. Ethanol was found not useful in the very acute period of post-injury. Additionally we studied these biomarkers in sera and cerebral tissues simultaneously. In this way we could tell which biomarker is more specific. We found that sera levels of insulin were higher than its tissue levels and tissue levels of GFAP, ethanol, IL-6 and nNOS were higher than their sera levels. Taking into account all of these results, we must also keep in mind that levels of these biomarkers may change depending on the severity of the trauma and time course.

\section{REFERENCES}

1. Berry C, Salim A, Alban R, Mirocha J, Margulies DR, Ley EJ: Serum ethanol levels in patients with moderate to severe traumatic brain injury influence outcomes: A surprising finding. Am Surg 76(10):1067-1070, 2010

2. Bonizzoli M, Zagli G, Lazzeri C, Deglınnocenti S, Gensini G, Peris A: Early insulin resistance in severe trauma without head injury as outcome predictor? A prospective, monocentric pilot study. Scand J Trauma Resusc Emerg Med 20(1):20-69, 2012

3. Bratasz A, Kuter I, Konior R, Goscinski I, Lukiewicz S: Nitric oxide as a prognostic marker for neurological diseases. Antioxid Redox Signal 6(3):613-617, 2004

4. Demir O, Kiymaz N, Ekin S, Yilmaz N, Ozbek H: Investigation of neuroprotective effect of dexamethasone by using nitric oxide and leukocyte levels in experimental head trauma. Int $\mathrm{J}$ Neurosci 117(12):1719-1730, 2007

5. Dudley R: Ethanol, fruit ripening, and the historical origins of human alcoholism in primate frugivory. Comparative Biology 44(4):315-323, 2004

6. Ekmark-Lewén S, Lewén A, Israelsson C, Li GL, Farooque M, Olsson Y, Ebendal T, Hillered L: Vimentin and GFAP responses in astrocytes after contusion trauma to the murine. Restor Neurol Neurosci 28(3):311-321, 2010

7. Erta M, Quintana A, Hidalgo J: Interleukin-6, a major cytokine in the central nervous system. Nt J Biol Sci 8(9):1254-1266, 2012

8. Harrison J, Frank L, Pardridge WM: A direct in vitro demonstration of insulin binding to isolated brain microvessels. Diabetes 30(1):757-761, 1981

9. He LM, Oiu BH, Oi ST, Fang LX, Liu XJ: Dynamic changes of serum interleukin- 6 and interleukin- 8 in patients with acute traumatic brain injury and the clinical significance. Nan Fang Yi Ke Da Xue Xue Bao 29(5):999-1001, 2009

10. Kanbak G, Kartkaya K, Ozcelik E, Guvenal AB, Kabay SC, Arslan G, Durmaz R: The neuroprotective effect of acute moderate alcohol consumption on caspase-3 mediated neuroapoptosis in traumatic brain injury: The role of lysosomal cathepsin L and nitric oxide. Gene 512(2):492-495, 2013
11. Logan BK, Jones AW: Endogenous ethanol 'auto-brewery syndrome' as a drunk-driving defence challenge. Med Sci Law 40(3):206-215, 2000

12. Marmarou A, Foda MA, Van Den Brink W, Campbell J, Kita $\mathrm{H}$, Demetriadou K: A new model of diffuse brain injury in rats. Part I: Pathophysiology and biomechanics. J Neurosurg 80(2): 291-300, 1994

13. Mondello S, Muller U, Jeromin A Streeter J, Hayes RL, Wang KK: Blood-based diagnostics of traumatic brain injuries. Expert Rev Mol Diagn 11(1):65-78,2011

14. Oliveira CO, Ikuta N, Regner A: Outcome biomarkers following severe traumatic brain injury. Rev Bras Ter Intensiva 20(4): 103-129, 2008

15. Pelinka LE, Kroepfl A, Leixnering M, Buchinger W, Raabe A, Redl H. GFAP versus S100B in serum after traumatic brain injury: Relationship to brain damage and outcome. J Neurotrauma 21(11):1553-1561, 2004

16. Pelinka LE, Kroepfl A, Schmidhammer R, Krenn M, Buchinger W, Redl H, Raabe A: Glial fibrillary acidic protein in serum after traumatic brain injury and multiple trauma. J Trauma 57(5):1006-1012, 2004

17. Pentelenyi T, Kammerer L, Stützel M, Balazsi I: Alterations of the basal serum insulin and blood glucose in brain-injured patients. Injury 10(3):201-208, 1979

18. Pentelenyi T, Kammerer L, Stützel M, Peter F: Changes in the blood sugar, serum insulin, cortisol and growth hormone levels in brain injuries. Magy Traumatol Orthop Helyreallito Seb 21(1):20-25, 1978

19. Pillion DJ, Haskell JF, Meezan E: Cerebral cortical microvessels: An insulin-sensitive tissue. Biochemical and Biophysical Research Communications 104(2):686-692, 1982

20. Rancan M, Morganti-Kossmann MC, Barnum SR, Saft S, Schmidt OI, Ertel W, Stahel PF: Central nervous systemtargeted complement inhibition mediates neuroprotection after closed head injury in transgenic mice. J Cereb Blood Flow Metab 23:1070-1074, 2003

21. Rangel-Castilla L, Robertso CS: Nitric oxide metabolism after traumatic brain injury. Intensive Care Medicine 3(1):739-747, 2007

22. Shohami E, Novikov M, Bass R, Yamin A, Gallily R: Closed head injury triggers early production of TNFa and IL- 6 by brain tissue. J Cereb Blood Flow Metab 14(1): 615-619, 1994

23. Ucar T, Tanriover G, Gurer I, Onal MZ, Kazan S: Modified experimental mild traumatic brain injury model. J Trauma 60(3):558-565, 2006

24. Vaz R, Sarmento A, Borges N, Cruz C, Azevedo T: Experimental traumatic cerebral contusion: Morphological study of brain microvessels and characterization of the oedema. Acta Neurochir (Wien) 140(1):76-81, 1998

25. Wada K, Chatzipanteli K, Busto R, Dietrich WD: Role of nitric oxide in traumatic brain injury in the rat. J Neurosurg 89(5): 807-818, 1998

26. Yang SH, Gustafson J, Gangidine M, Stepien D, Schuster R, Pritts TA, Goodman MD, Remick DG, Lentsch AB: A murine model of mild traumatic brain injury exhibiting cognitive and motor deficits. J Surg Res 184(2):981-988, 2013

27. Zetterberg $\mathrm{H}$, Smith $\mathrm{DH}$, Blennow K: Biomarkers of mild traumatic brain injury in cerebrospinal fluid and blood. Nat Rev Neurol 9(1):201-210, 2013

28. Ziaja M, Pyka J, Boczkus B, Plonka BK, Plonka PM: Changes in the nitric oxide level in the rat liver as a response to brain injury. Nitric Oxide 25(4):423-430, 2011 